\title{
Follow-up on Ujarassiorit mineral hunt finds and outreach activities, South-East Greenland
}

\author{
Majken D. Poulsen, Holger Paulick, Diogo Rosa, Vincent J. van Hinsberg, Jonas Petersen and \\ Lærke L. Thomsen
}

In connection with field work in South-East Greenland in 2014, we took the opportunity to examine the geology associated with potentially valuable mineral occurrences found by local rock collectors. The initial finds were made by local collectors as part of Ujarassiorit, which is an annual mineral hunt competition where anyone in Greenland can submit samples of rocks they have found in the countryside for closer examination by the Ministry of Mineral Resources (see www.ujarassiorit.gl). In the Tasiilaq region, Ujarassiorit resulted in finds of corundum, precious metal and base-metal mineral occurrences. Our intention was to locate the original sample sites with help from the local rock collectors, describe the geological context and assess the potential for mineral exploration. Further work will include laboratory analyses of rock samples and geological reporting.

Since the base camp in 2014 was located in the settlement Kuummiut, we made an effort to engage the local people in outreach activities. The aim was to explain what type of work geologists conduct and how different rocks and minerals can be distinguished. We also visited adjacent communities where the idea was to develop local field guides for teachers, interested citizens and tourists.

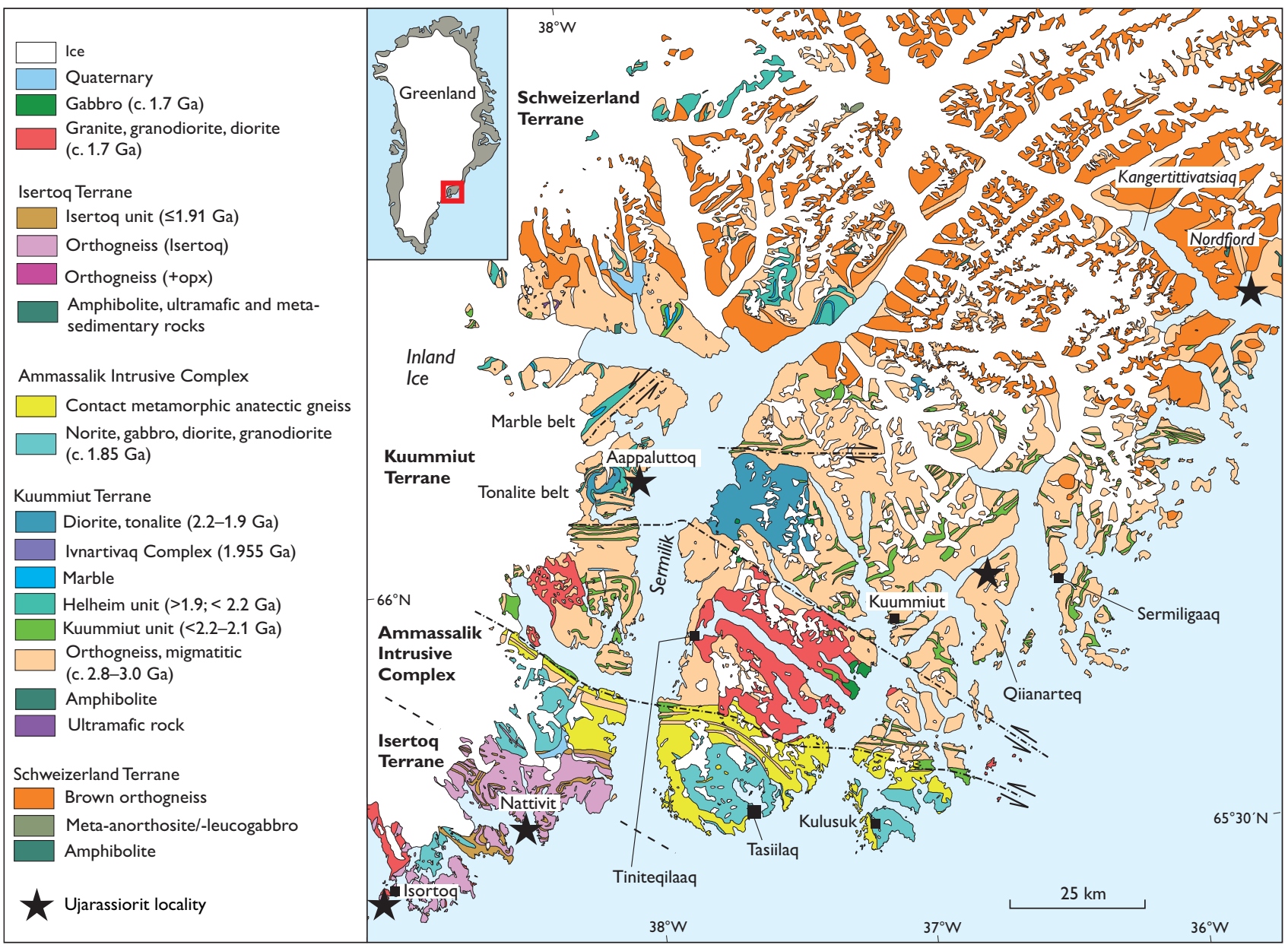

Fig. 1. Geological map of the Tasiilaq area in South-East Greenland, modified from Escher (1990) and Kolb (2014). 


\section{Precious metal mineral occurrence north of Tasiilaq}

During field work, the winner of two Ujarassiorit prizes, William Umerineq from Kuummiut, showed the field team the locations of his winning samples. One sample was described by the Ujarassiorit jury as a sulphide-bearing, garnet-rich amphibolite rich in platinum-group elements, cobalt and copper; it was collected at Ilitti close to Nordfjord at the outer part of Kangertittivatsiaq (Fig. 1). The rock contains 44.5\% Fe, $>1 \% \mathrm{Cu}, 5280$ ppm Ni, 2340 ppm Co, 804 ppb Au and 284 ppm Pd. The other sample was collected near Aappaluttoq in the fjord of Sermilik; it had been described as a graphite and garnet gneiss and it had a gold content of $11.1 \mathrm{ppm}$.

At the Ilitti locality, a pegmatite lens with coarse-grained calcite was found during field work (Fig. 2A). The origin of the calcite is uncertain; it could come from marble remnants within the host gneiss, from a carbonatite occurrence or it could be of hydrothermal origin. Epidote and actinolitebearing, calc-silicate assemblages developed along the con- tact between calcite and the pegmatite, and small sulphide pods are found locally. Such a sulphide pod submitted to the Ujarassiorit was confirmed to be rich in precious metals, cobalt and copper during our follow-up work.

At Aappaluttoq, the rock collector William Umerineq showed us a garnet-rich (garnetite) horizon (Fig. 2B). This horizon seems to belong to one of several discontinuous and foliation-concordant, garnet-rich bodies that are present within yellow-weathering, graphitic mica schist. These garnet-rich bodies are probably boudins that formed due to deformation of the garnet-rich rock or its precursor. In some areas, these bodies are closely related to subhorizontal pegmatite sheets, which were also dismembered into boudins. No sulphides were identified in these garnet-rich bodies during field work. However, since Umerineq's sample was very similar in appearance to the garnet-rich bodies that we found, we undertook an extensive sampling effort in the area. Other samples were collected from silicified domains, veins and veinlets that contain sulphides or gossanised material. Laboratory analyses failed to confirm the presence of
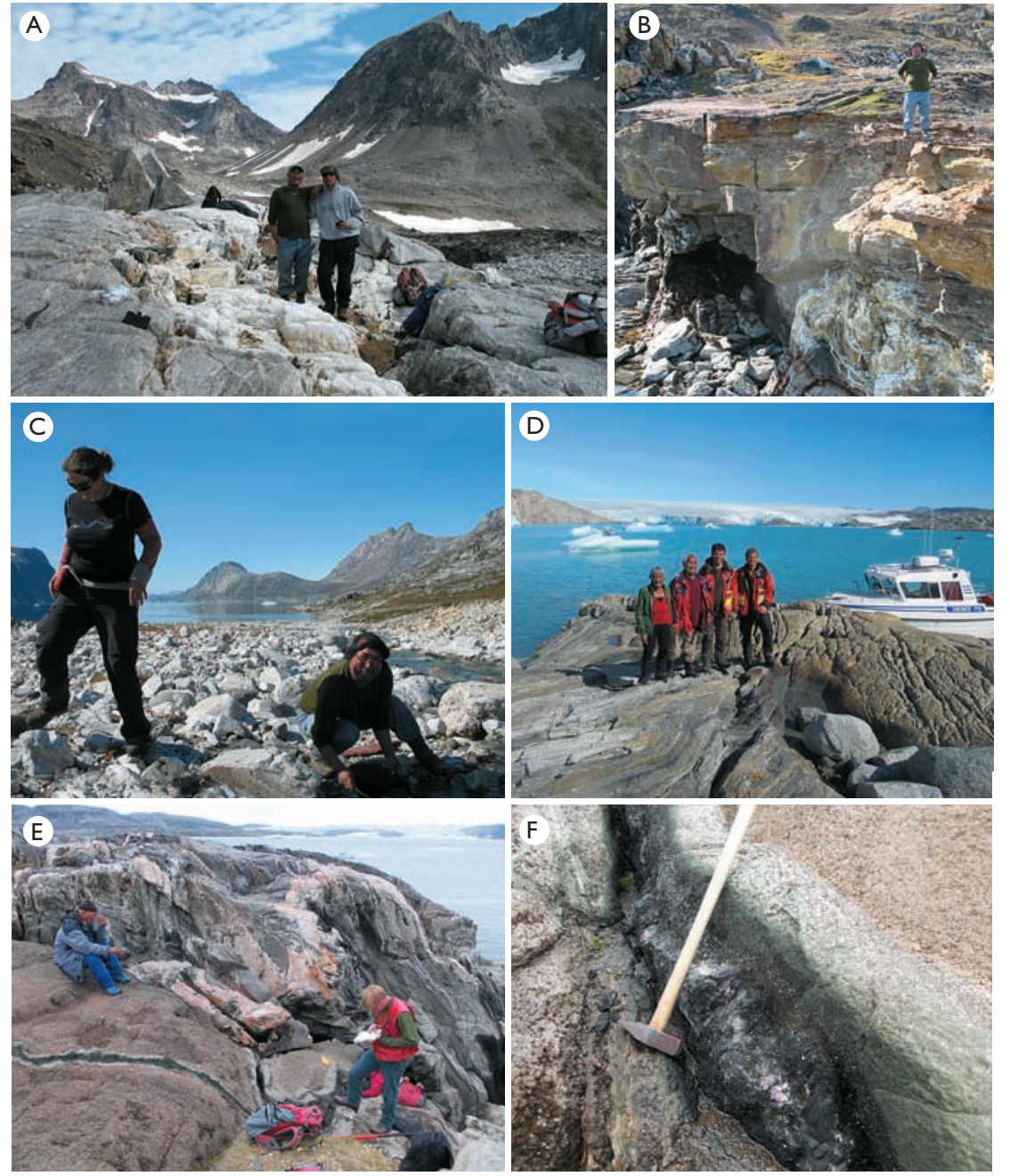

Fig. 2. A: William Umerineq (to the left) at the location where he collected a prize-winning Ujarassiorit sample at Ilitti in the Kangertittivatsiaq fjord area. B: William Umerineq standing above the shoreline where he collected another prize-winning, gold-rich Ujarassiorit sample near Aappaluttoq. The locality is only accessible at low tide. C: William Umerineq panning stream sediments to separate possible gold grains on the island of Qiianarteq. D: In the Isortoq area, Dines and Rosa Jonathansen (first and second from left) took the field team to several of the sites where they had collected rock samples for the Ujarassiorit competition. E: The corundum locality was found with help from Vittus Sakæussen, the 2009 Ujarassiorit prize-winner. The geologists are examining ultramafic rocks containing veins with pink corundum; Vittus Sakæussen is sitting on the ultramafic rock and a light pinkish granitic pegmatite is seen between them. The vein in the ultramafic rock shows several progressive reaction zones. F: Biotite, amphibole and pink corundum were formed during the final stages in the development of the metasomatic vein. 
gold in the garnet-rich rock, but anomalous gold values (up to $463 \mathrm{ppb}$ ) were recorded in a few of the veins and veinlets. This indicates that the original Ujarassiorit sample might also have included such a vein or veinlet and that nuggeteffects could account for the differences in gold concentration between that sample and the ones collected during the follow-up in 2014.

The collectors of additional Ujarassiorit samples from 1993, 1999 and 2007 with high gold concentrations could not be contacted or accompany us to help locate their sample sites. The first two samples were erratics whereas the third was in situ, but its precise location is unknown. In order to follow up on these samples, gold panning was carried out in areas with large drainage basins on the island of Qiianarteq and on the adjacent peninsula north of Qiianarteq (Fig. 2C). However, the panning effort failed to show any significant gold.

\section{Follow-up on copper mineral occurrences in the Isortoq archipelago}

The area around the settlement of Isortoq is characterised by an archipelago consisting of banded gneiss with amphibolite bodies hosting granite intrusions. Pegmatite dykes and quartz veins are also common. The field work focused on visiting islands and localities with reported copper mineral occurrences (up to $1.9 \% \mathrm{Cu}$ ) in order to describe the geological setting and assess the potential of these occurrences. Samples from these localities were submitted to Ujarassiorit between 1990 and 2012. Some of the sites were visited with the rock collectors, Dines and Rosa Jonathansen (Fig. 2D), and this proved to be a good approach to explore several sites in a time-efficient way.

We observed a number of different styles of sulphide occurrences in the area: (1) amphibolite with late-stage brittle fractures with quartz, epidote and pyrite with malachite staining, (2) pyrite within quartz veins, (3) pyrite-chalcopyrite dissemination or veins within pegmatite dykes, (4) sulphide-bearing granitic or gabbroic boudins within banded gneiss, (5) disseminated sulphide in banded gneiss and (6) rounded boulders of sulphide-bearing gabbro in a moraine close to the margin of the Inland Ice. A soapstone occurrence was also identified that is apparently used by local craftsmen as raw material for their work.

Overall, the field work showed that the known sulphide occurrences are small and commonly lack signs of large-scale hydrothermal alteration. Where sulphide occurrences were encountered the visual estimates of pyrite and chalcopyrite concentrations are commonly around 1-2 vol.\%. Hence, our field work gave little encouragement for additional efforts to explore for economically significant copper deposits in the area.

\section{Follow-up on a corundum sample from the Ujarassiorit prize-winner in 2009}

Several occurrences of corundum $\left(\mathrm{Al}_{2} \mathrm{O}_{3}\right)$ were investigated, and we focused our effort on an occurrence on a small island off Immikkeerteq near Nattivit (Fig. 1). This corundum locality was visited with the help of the rock collector Vittus Sakæussen, who initially found it and won the first prize in the 2009 Ujarassiorit competition. A preliminary understanding of the formation history of the Nattivit occurrence allowed the field team to identify a number of additional corundum occurrences.

All occurrences share the same characteristics: corundum occurs where late-stage felsic pegmatites crosscut and interact with metamorphosed ultramafic rocks (Fig. 2E). A progressive metasomatic change of the pegmatite took place at the contact with the ultramafic body, where progressive subsequently varying mineral zones developed with more and more silica-depleted bulk compositions culminating in a biotite zone, followed by a zone with black amphibole and pink corundum at the centre (Fig. 2F). This sequence of mineral zoning was found as a concentric arrangement along the length of the pegmatite dyke with successively increasing development as the dyke protrudes farther into the metamorphosed ultramafic rock. The corundum crystals are generally large (locally up to $5 \mathrm{~cm}$ in diameter) and anhedral with minimal fracturing. This mode of occurrence as isolated, large grains suggests that metasomatic replacement took place under conditions where element mobility was high. The source of the aluminium appears to be plagioclase in the pegmatite with removal of silica by interaction with the ultramafic rock which ultimately led to $\mathrm{Al}_{2} \mathrm{O}_{3}$ saturation.

The process of formation is local and linked to element exchange between ultramafic rocks and late-stage pegmatite dykes. Both these lithologies are common throughout the field area, and metasomatic reaction zones between them are ubiquitous. However, most of the reaction zones only developed biotite, without black amphibole or corundum.

Older generations of metasomatic interaction between pegmatites and ultramafic rock units are present, but these lack corundum. The metamorphosed ultramafic rocks are mainly sills or dykes that occur as intrusions in a tonaliteamphibolite gneiss basement. Black amphibole rims developed at the contact between the intrusion and the gneiss, but no other mineral zones were observed.

\section{General outreach and education}

The geology near Kuummiut, Tiniteqilaaq, Sermiligaaq, $\mathrm{Ku}$ lusuk and Tasiilaq was studied and rock samples collected as 

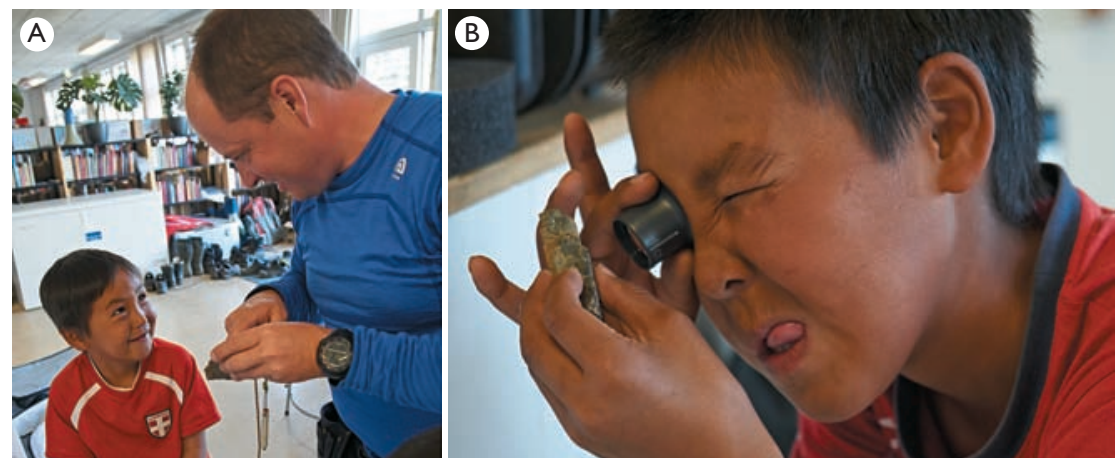

Fig. 3. A: A geologist from GEUS teaching children in Kuummiut how to use a hand lens and how to recognise different minerals. B: Robert Umerineq enthusiastically studies a rock sample. Photographs: Jakob Lautrup

a basis for local geological field guides. The intention is to engage school teachers and other interested citizens to develop a better understanding of the local geology, the science of geology and geological field work in general. The local people are already familiar with their local environment and landscapes, and this will allow them to interpret what they see, and teach this to the next generation.

The five communities represent diverse geology and cover a wide spectrum of themes, which taken together, can tell a story of a dynamic geological history of this part of SouthEast Greenland. A variety of geological structures and processes can be studied, such as relations between intrusions at Kulusuk and Tasiilaq, contact metamorphism at Tiniteqilaaq, deformation and metamorphism at Kuummiut and an igneous fractionation series at Sermiligaaq. The smaller settlements are well suited for geological outreach because they show the most interesting igneous and metamorphic geology, whereas a fairly uniform geology is exposed around the town of Tasiilaq. We collected samples that can provide mineralogical, petrological and geochronological information, as well as data on geochemical compositions and thin section photographs for the field guides. The field guides will be written following analyses of the rock samples, and will contain background information on geological processes and features.

Shortly after the beginning of the school year in 2014, a geology theme day about basic geology with demonstrations of the typical rock types in Kuummiut was held at the primary school in Kuummiut for 6-12 years old children (Fig. 3). Furthermore, a community information meeting was arranged at the school in Kuummiut, where we presented the aims of the field activities in the Tasilaq area. The meeting and presentations were well-received and more than 30 citizens of Kuummiut attended.

\section{Conclusions}

The experience from this field season shows that the followup of mineralised samples submitted to the Ujarassiorit programme is best carried out with the help of local rock collectors. This has proved to be the most efficient way to quickly find the right areas, since the limited time in the field makes it important to get to the right locations as quickly as possible. Also, we found that engaging the local community members in the field work contributed to a better understanding of what geologists are doing in the field and how this work may ultimately benefit the Greenlandic community.

Our experience shows that especially children enjoy exploring their natural surroundings and are eager to learn about rocks and the work carried out by geologists. Field guides and further outreach will be appreciated by the local people and will hopefully lead to a self-sustainable situation where school teachers and interested citizens acquire sufficient geological background knowledge to explain their local geology.

\section{Acknowledgements}

This study is a joint project financed by the Government of Greenland and the Geological Survey of Denmark and Greenland. We are grateful to the rock collectors who shared their local knowledge with us and to the people of Kuummiut and Isortoq for support and for their enthusiasm for our work. Hans Kristian Olsen kindly commented on the manuscript.

\section{References}

Escher, J.C. 1990: Geological map of Greenland, 1:500 000, Skjoldungen, sheet 14. Copenhagen: Geological Survey of Greenland.

Kolb, J. 2014: Structure of the Palaeoproterozoic Nagssugtoqidian Orogen, South-East Greenland: model for the tectonic evolution. Precambrian Research 255, 809-822.

\footnotetext{
Authors' addresses

M.D.P., Geological Survey of Denmark and Greenland, Nuuk Office, Kivioq 2, 3900 Nuuk, Greenland; E-mail: madp@geus.dk

H.P. \& D.R., Geological Survey of Denmark and Greenland, Øster Voldgade 10, Dk-1350, Copenhagen K, Denmark.

V.J.v.H., Department of Earth \& Planetary Sciences, 3450 University Street, Montreal, Quebec, Canada H3A 2 A7.

J.P.\& L.L.T., Ministry of Mineral Resources, Postbox 930, Imaneq 1A, 201, 3900 Nuuk, Greenland.
} 